\title{
Critical Micelle Concentration of Surfactant Using Hadkar Factor
}

\author{
Ulhas Balkrishna Hadkar* and Asavari Sameer Hadkar \\ Department of Pharmaceutics Mumbai Educational Trust's Institute of Pharmacy, Bandra (w), Mumbai - 400 50. (M.S.), INDIA.
}

\begin{abstract}
Critical micelle concentration is an important characteristic property of a surfactant and various methods such as osmotic pressure, surface tension, interfacial tension, UV-Visible spectrophotometry have been reported to determine it. The drop weight method was used to determine the Hadkar factor $\mathrm{H}_{1}$ for organic liquid lighter than water and Hadkar factor $\mathrm{H}_{2}$ was used for organic liquid heavier than water. The plot of $\mathrm{H}_{1}$ or $\mathrm{H}_{2}$ vs concentration of the aqueous surfactant solution was used to determine the critical micelle concentration of the surfactant. Interfacial tension between the aqueous surfactant solution and the organic liquid was also determined using Hadkar factors $\mathrm{H}_{1}$ and $\mathrm{H}_{2}$.
\end{abstract}

Key words: Drop weight method, Hadkar factors, Interfacial tension, critical micelle concentration, surfactant, pipette.

\section{INTRODUCTION}

Surfactants are surface active agents and a surfactant molecule has both hydrophilic part and hydrophobic (lipophilic) part and as a result the surfactant molecules are adsorbed at the interface of immiscible phases, and thereby reduce the interfacial tension. ${ }^{1}$ As the concentration of surfactant is increased, the surface tension goes on decreasing and at a certain concentration, the monomer surfactant " $n$ " molecules associate to form aggregates called micelles. ${ }^{2,3}$ The process of formation of micelles is termed as micellization. The minimum concentration at which micelle formation takes place is called the critical micelle concentration (cmc) and is temperature dependent. The methods such as pendant drop method, Withelmy plate method, have been reported to determine interfacial tension between two liquids. ${ }^{4}$ The $\mathrm{cmc}$ of a surfactant can be determined by various methods such as osmotic pressure, surface tension, interfacial tension, conductivity method. ${ }^{5}$ The plot of the physical quantity vs the surfactant solution concentration shows a sudden change in the measured physical quantity at the cmc of the surfactant and this fact is used to determine the critical micelle concentration. ${ }^{6}$ The method reported here to determine the Interfacial Tension between organic liquid and surfactant solution is the drop weight method same as that reported by Hadkar U.B. and Ravindra R.P. ${ }^{7}$ The drop weight method was used to determine Hadkar Factor $\mathrm{H}_{1}$ for two different systems, namely, the aqueous surfactant Tween-20 solution-butanol system and cetyl trimethyl ammonium bromide (CTAB) aqueous surfactant solution-butanol system. Also Hadkar Factor $\mathrm{H}_{2}$ was determined for two different systems, namely, $\mathrm{CCl}_{4}$ - Tween-20 aqueous solution and $\mathrm{CCl}_{4}-\mathrm{CTAB}$ aqueous solution.

\section{MATERIAL AND METHOD}

Carbon tetrachloride and butanol:-AR grade, S.D. Fine Chemicals.

Tween-20 and cetyl triammonium bromide (CTAB):- Central Drug House (CDH)
Submission Date :22/08/2014

Revision Date : :14/10/2014

Accepted Date : :23/12/2014

DOI: 10.5530/ijper.49.2.9

Correspondence Address

Dr. U.B. Hadkar

Director,

Mumbai Educational Trust Institute of Pharmacy,

Bhujbal Knowledge Centre, Bandra (w), Mumbai-400050. Email:ulhashadkar@yahoo. com

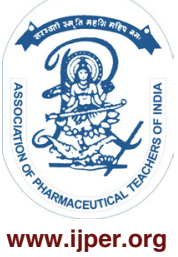


Method for organic liquids heavier than water (or aqueous surfactant solution)

\section{$\mathrm{CCl}_{4}$ and aqueous solution of Tween-20}

The lighter liquid Tween-20 aqueous solution was taken in a $100 \mathrm{ml}$ beaker placed in a petri dish. A volumetric pipette (inner radius $\mathrm{r}=0.062 \mathrm{~cm}$ ) filled with $\mathrm{CCl}_{4}$ (heavier liquid) was held in a vertical position and the tip of the pipette was just dipped into the aqueous solution. The number of drops of $\mathrm{CCl}_{4}$ in the aqueous solution was determined for a fixed volume $(3.5 \mathrm{ml})$. The drop rate was about 8-10 drops per minute. The volume of the liquid could be measured accurately by pasting a strip of graph paper on the upper and lower stem of the pipette. The number of drops of $\mathrm{CCl}_{4}$ in the aqueous solution of surfactant was determined for various concentrations of Tween-20 ( $0 \mathrm{mg} / 100 \mathrm{ml}$ to $16 \mathrm{mg} / 100$ $\mathrm{ml})$. The number of drops per $3.5 \mathrm{ml}$ of $\mathrm{CCl}_{4}$ in air and that of the aqueous solution of Tween-20 in air were also determined. The data is given in Table1.

\section{$\mathrm{CCl}_{4}$ and aqueous solution of CTAB}

The number of drops of $\mathrm{CCl}_{4}$ in the aqueous CTAB solution was determined per $3.5 \mathrm{ml}$ using the same pipette $(\mathrm{r}=0.062 \mathrm{~cm})$ used in the part $(\mathrm{A})$. The number of drops of $\mathrm{CCl}_{4}$ in aqueous solution of surfactant was determined for various concentrations of CTAB $(0$ $\mathrm{mg} / 100 \mathrm{ml}$ to $50 \mathrm{mg} / 100 \mathrm{ml}$ ). The number of drops of aqueous solution of CTAB in air were also determined using the same pipette and for the same volume (3.5 $\mathrm{ml})$. The data is given in the Table 2 .

\section{Method for organic liquids lighter than water (or aqueous solution of surfactant)}

\section{Aqueous Tween- 20 solution and butanol}

The procedure followed was the same as in the part (A). The heavier liquid (aqueous Tween-20 solution, concentration $0 \mathrm{mg} / 100 \mathrm{ml}-16 \mathrm{mg} / 100 \mathrm{ml}$ ) was taken in the pipette (radius $\mathrm{r}=0.026 \mathrm{~cm}$ ) and the number of drops per $4 \mathrm{ml}$ in butanol was determined. The number of drops of butanol per $4 \mathrm{ml}$ in air as well as the number of drops per $4 \mathrm{ml}$ for each aqueous Tween- 20 solution in air was also determined, using the same pipette. The data is given in the Table 3 .

\section{Aqueous solution of CTAB and butanol}

The method used was the same as in the part (A). The heavier liquid (aqueous CTAB solution, concentration 0 $\mathrm{mg} / 100 \mathrm{ml}-50 \mathrm{mg} / 100 \mathrm{ml}$ ) was taken in the pipette ( $\mathrm{r}$ $=0.062 \mathrm{~cm}$ ) and the number of drops per $3.5 \mathrm{ml}$ in butanol was determined. The number of drops of butanol per $3.5 \mathrm{ml}$ in air as well as number of drops per $3.5 \mathrm{ml}$ of each aqueous CTAB solution in air was also deter- mined, using the same pipette. The data is given in the Table 4.

Calculation for the Hadkar Factor $\mathrm{H}_{1}$ (Organic liquid lighter than the aqueous solution):

The Hadkar factor $\mathrm{H}_{1}$ is given by

$$
H_{1}=\frac{\left(n^{\text {org. air }}\right)}{\left(n^{\text {aqueous.air }}\right)}
$$

where, $\mathrm{n}^{\text {org. air }}=$ number of drops of organic liquid in air for a given volume $\mathrm{V}$.

$\mathrm{n}^{\text {aqueous air }}=$ number of drops of aqueous solution in air for the same volume $\mathrm{V}$, using the same pipette (same radius).

Calculation for the Hadkar Factor $\mathrm{H}_{2}$ (Organic liquid heavier than aqueous solution):

The Hadkar factor $\mathrm{H}_{2}$ is given by

$$
H_{2}=\frac{\left(n^{\text {org. aqueous }}\right)}{\left(n^{\text {org. air }}\right)-\left(n^{\text {aqueous.air }}\right)}
$$

where, $\mathrm{n}^{\text {org. aqueous }}=$ number of drops of organic liquid in aqueous solution for the given volume $\mathrm{V}$.

$\mathrm{n}^{\text {org. air }}=$ number of drops of organic liquid in air for the same volume $\mathrm{V}$.

$\left(\mathrm{n}^{\text {aqueous air }}\right)=$ number of drops of aqueous solution in air for the same volume V, using the same pipette (same radius)

Calculation for interfacial tension between the surfactant solution and the immiscible organic liquid:

When the drop of the heavier liquid is about to detach from the tip of the pipette inside the lighter liquid,

that is, at the equilibrium,

$$
\begin{aligned}
& m g=2 \pi r \gamma_{i n t} H_{1} \ldots \ldots \ldots \ldots \ldots \ldots \text { (3) } \\
& m g=2 \pi r \gamma_{i n t} H_{2} \ldots \ldots \ldots \ldots \ldots \ldots \text { (4) }
\end{aligned}
$$

where,

$\mathrm{m}=$ apparent mass of the drop inside the liquid. ${ }^{8}$

Note: The apparent mass of heavier liquid drop is less than the true mass of the liquid drop because of the up-thrust of the lighter liquid.

$\mathrm{g}=$ acceleration due to gravity $=980 \mathrm{~cm} / \mathrm{sec}^{2}$

$\mathrm{r}=$ radius of the tip of the pipette in $\mathrm{cm}$.

$\gamma_{\text {int }}=$ Interfacial tension between the two liquids

$\mathrm{H}_{1}$ = Hadkar factor when the aqueous solution is heavier than the organic liquid

(Given by equation 1)

$\mathrm{H}_{2}=$ Hadkar factor when the aqueous solution is lighter than the organic liquid. 


\begin{tabular}{|c|c|c|c|c|c|c|c|c|}
\hline $\begin{array}{c}\mathrm{C} \mathrm{mg/100} \\
\mathrm{ml}\end{array}$ & $\begin{array}{l}\mathrm{n}^{\top 20} \text { in air } \\
\text { per } 3.5 \mathrm{ml}\end{array}$ & $\begin{array}{l}\mathrm{n}_{4}^{\mathrm{CCl}} \text { in } \mathrm{T} 20 \\
\text { per } 3.5 \mathrm{ml}\end{array}$ & $\mathrm{H}_{2}$ & $\mathbf{v}(\mathrm{ml})$ & $m_{0}(g m)$ & m (gm) & $Y_{\text {int }}$ dyn/cm & SD \pm \\
\hline 0 & 54 & 127 & 0.709 & 0.0275 & 0.04364 & 0.01609 & 57.08 & 0.56 \\
\hline 2 & 60 & 130 & 0.751 & 0.0269 & 0.04265 & 0.01572 & 52.60 & 0.55 \\
\hline 4 & 60 & 133 & 0.768 & 0.0263 & 0.04168 & 0.01537 & 50.32 & 0.56 \\
\hline 6 & 65 & 147 & 0.875 & 0.0238 & 0.03771 & 0.01319 & 39.99 & 0.56 \\
\hline 8 & 67 & 154 & 0.928 & 0.0227 & 0.0360 & 0.01327 & 35.99 & 0.57 \\
\hline 10 & 71 & 160 & 0.988 & 0.0218 & 0.03465 & 0.01278 & 32.54 & 0.56 \\
\hline 12 & 71 & 175 & 1.080 & 0.0200 & 0.03168 & 0.01168 & 27.23 & 0.57 \\
\hline 14 & 71 & 175 & 1.080 & 0.0200 & 0.03168 & 0.01168 & 27.23 & 0.56 \\
\hline 16 & 72 & 178 & 1.106 & 0.0197 & 0.03115 & 0.01148 & 26.13 & 0.54 \\
\hline \multicolumn{9}{|c|}{$\begin{array}{l}\text { The values of } \gamma_{\text {int }} \text { are the average values of } 5 \text { readings. } \\
r=\text { Radious of the tip the pipette }=0.062 \mathrm{~cm}\end{array}$} \\
\hline \multicolumn{9}{|c|}{ Hadkar factor, $\mathrm{H}_{2}=\frac{\left(n^{\mathrm{CCl} / 4} \text { in } \mathrm{T}-20\right)}{\left(n^{\mathrm{CC} 14} \text { in air }-n^{\mathrm{T}-20} \text { in air }\right)}$} \\
\hline $\begin{array}{l}\mathrm{n}^{\mathrm{cc}} \\
\mathrm{n}^{\mathrm{T}=} \\
\mathrm{n}^{\mathrm{cc}} \\
\gamma_{\text {int }} \\
\mathrm{C}^{\mathrm{c}}= \\
\mathrm{g}= \\
\mathrm{v}= \\
\mathrm{m} \\
\mathrm{m}\end{array}$ & $\begin{array}{l}\text { air }=\text { number of } \\
\text { air }=\text { number of } \\
\mathrm{T}-20=\text { number } \\
\text { terfacial tensio } \\
\text { ncentration of a } \\
\text { eleration due tc } \\
\text { in } c c \text { of } 1 \text { drop } \\
\left(\rho-\rho^{\prime}\right) / \rho=a p \\
\text { ve mass of the }\end{array}$ & $\begin{array}{l}\text { ops of } \mathrm{CCl}_{4} \text { in air } \\
\text { ops of aqueous s } \\
\text { trops of } \mathrm{CCl}_{4} \text { in } \\
\text { etween } \mathrm{CCl}_{4} \text { and } \\
\text { eous } \mathrm{Tween}^{-20 \mathrm{~s}} \\
\text { avity }=980 \mathrm{~cm} / \mathrm{s} \\
\mathrm{Cl}_{4} \text { in } \mathrm{Tween}^{2} \mathrm{O} \\
\text { ent mass of } \mathrm{CCl} \\
4 \text { drop in } \mathrm{gm}=\mathrm{v}\end{array}$ & $\begin{array}{l}.5 \mathrm{ml}=233 \\
\text { on of Twee } \\
\text { us Tween- } \\
\text { aqueous } \mathrm{TV} \\
\text { on in } \mathrm{mg} / \mathrm{c} \\
\\
\text { ion }=3.5 / \\
\text { in the aqu }\end{array}$ & $\begin{array}{l}\text { ir. } \\
\text { ion. } \\
\text { solution = } \\
20 \\
\text { een-20 solu }\end{array}$ & $(g / 2 \pi r)$ & & & \\
\hline
\end{tabular}

\section{Table 2: Hadkar factor $\mathrm{H}_{2}$ and the Interfacial tension between $\mathrm{CCl}_{4}$ and $\mathrm{CTAB}$ aqueous solutions at $28^{\circ} \mathrm{C} \pm 1^{\circ} \mathrm{C}$}

\begin{tabular}{|c|c|c|c|c|c|c|c|c|}
\hline $\begin{array}{c}\mathrm{C} \mathrm{mg/100} \\
\mathrm{ml}\end{array}$ & $\begin{array}{l}\mathrm{n}^{\text {CTAB }} \text { air } \\
\text { per } 3.5 \mathrm{ml}\end{array}$ & $\begin{array}{c}\mathrm{n}^{\mathrm{CCl}} \text { in } \\
\text { CTAB per } \\
3.5 \mathrm{ml}\end{array}$ & $\mathrm{H}_{2}$ & $v(m L)$ & $m_{0}(g m)$ & m (gm) & $\begin{array}{c}Y_{\text {int }} \text { dynes } / \\
\text { cm }\end{array}$ & SD \pm \\
\hline 0 & 54 & 133 & 0.743 & 0.0263 & 0.04168 & 0.015369 & 49.5 & 0.92 \\
\hline 5 & 66 & 154 & 0.922 & 0.0227 & 0.0360 & 0.01327 & 36.2 & 0.89 \\
\hline 10 & 71 & 179 & 1.105 & 0.0196 & 0.0309 & 0.01142 & 26.0 & 0.92 \\
\hline 15 & 80 & 229 & 1.497 & 0.01528 & 0.0242 & 0.00893 & 15.0 & 0.85 \\
\hline 20 & 84 & 343 & 2.302 & 0.01020 & 0.0162 & 0.00596 & 6.5 & 0.84 \\
\hline 25 & 94 & 768 & 5.525 & 0.00456 & 0.00722 & 0.002662 & 1.2 & 0.75 \\
\hline 30 & 101 & 1877 & 14.219 & 0.001865 & 0.00295 & 0.001089 & 0.19 & 0.77 \\
\hline 35 & 104 & 1828 & 14.171 & 0.0019147 & 0.00303 & 0.001118 & 0.19 & 0.78 \\
\hline 40 & 105 & 1849 & 14.445 & 0.001893 & 0.002998 & 0.001105 & 0.19 & 0.68 \\
\hline 45 & 105 & 1768 & 13.813 & 0.001979 & 0.00314 & 0.001156 & 0.21 & 0.62 \\
\hline 50 & 105 & 1946 & 15.203 & 0.001799 & 0.002849 & 0.00105 & 0.17 & 0.65 \\
\hline
\end{tabular}

The values of $\gamma_{\text {int }}$ are the average values of 5 readings.

$r=$ radious of the tip the pipette $=0.062 \mathrm{~cm}$

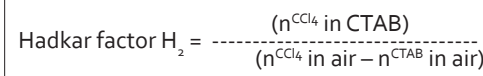

$\mathrm{n}^{\mathrm{CCl}} 4 \mathrm{in}$ air = number of drops of $\mathrm{CCl}_{4}$ in air per $3.5 \mathrm{ml}=233$

$n^{\text {CTAB }}$ in air = number of drops of aqueous solution of CTAB in air.

$\mathrm{n}^{\mathrm{CCl}_{4}}$ in $\mathrm{CTAB}=$ number of drops of $\mathrm{CCl}_{4}$ in aqueous $\mathrm{CTAB}$ solution.

$\gamma_{\text {int }}=$ Interfacial tension between $\mathrm{CCl}_{4}$ and the aqueous $C T A B$ solution $=(\mathrm{m} / \mathrm{H} 2) \cdot(\mathrm{g} / 2 \pi \mathrm{r})$

$\mathrm{C}=$ Concentration of aqueous $\mathrm{CTAB}$ solution in $\mathrm{mg} / 100 \mathrm{ml}$

$\mathrm{g}=$ acceleration due to gravity $=980 \mathrm{~cm} / \mathrm{sec}^{2}$

$v=$ vol. in c.c. of 1 drop of $\mathrm{CCl}_{4}$ in CTAB solution $=3.5 / \mathrm{n}^{\mathrm{CCl}} 4$ in $\mathrm{CTAB}$

$m=m_{0}\left(\rho-\rho^{\prime}\right) / \rho=$ apparent mass of $C_{C l}$ drop in the aqueous $C T A B$ solution.

$\mathrm{m}_{0}=$ True mass of the $\mathrm{CCl}_{4}$ drop in $\mathrm{gm}=\mathrm{v}$. $\rho$

$\rho=$ density of the heavier liquid $\mathrm{CCl}_{4}=1.584 \mathrm{gm} / \mathrm{cc}$

$\rho^{\prime}=$ density of the lighter liquid (aqueous $C T A B$ solution) $=1 \mathrm{gm} / \mathrm{c} . \mathrm{C}$

Note : The density of aqueous CTAB solution is considered the same as the density of water. 
(Given by equation 2)

\section{RESULTS AND DISCUSSION}

Hadkar factor $\mathrm{H}_{2}$ was calculated for $\mathrm{CCl}_{4}$ and the aqueous surfactant solution of Tween-20 and is given in Table 1 and Hadkar Factor $\mathrm{H}_{2}$ calculated for $\mathrm{CCl}_{4}$ and the aqueous surfactant solution of CTAB is given in Table 2.

Hadkar factor $\mathrm{H}_{1}$ calculated for aqueous surfactant solution of Tween-20 and butanol is given in the Table 3 and Hadkar Factor $\mathrm{H}_{1}$ calculated for the aqueous surfactant solution of CTAB and butanol is given in Table 4.

\begin{tabular}{|c|c|c|c|c|c|c|c|c|}
\hline $\begin{array}{c}\mathrm{C} \\
\mathrm{mg} / 100 \mathrm{ml}\end{array}$ & $\begin{array}{c}\mathrm{n}^{\text {Tween-20 }} \text { air } \\
\text { per } 4 \mathrm{ml}\end{array}$ & $\begin{array}{c}\mathrm{n}^{\text {Tween-20 }} \text { in } \\
\text { butanol per } \\
4 \mathrm{ml}\end{array}$ & $\mathrm{H}_{1}$ & $\mathrm{v}(\mathrm{ml})$ & $m_{0}(g m)$ & m (gm) & $\begin{array}{c}Y_{\text {int }} \text { dynes/ } \\
\text { cm }\end{array}$ & SD \pm \\
\hline 0 & 86 & 828 & 2.616 & $4.83 \times 10^{-3}$ & $4.83 \times 10^{-3}$ & $0.918 \times 10^{-3}$ & 2.10 & 0.02 \\
\hline 2 & 90 & 934 & 2.50 & $4.283 \times 10^{-3}$ & $4.283 \times 10^{-3}$ & $0.8139 \times 10^{-3}$ & 1.95 & 0.021 \\
\hline 4 & 90 & 940 & 2.50 & $4.255 \times 10^{-3}$ & $4.255 \times 10^{-3}$ & $0.8085 \times 10^{-3}$ & 1.93 & 0.019 \\
\hline 6 & 103 & 965 & 2.184 & $4.145 \times 10^{-3}$ & $4.145 \times 10^{-3}$ & $0.7876 \times 10^{-3}$ & 2.16 & 0.02 \\
\hline 8 & 107 & 1029 & 2.103 & $3.887 \times 10^{-3}$ & $3.887 \times 10^{-3}$ & $0.7386 \times 10^{-3}$ & 2.10 & 0.023 \\
\hline 10 & 109 & 1182 & 2.064 & $3.841 \times 10^{-3}$ & $3.841 \times 10^{-3}$ & $0.64298 \times 10^{-3}$ & 1.86 & 0.024 \\
\hline 12 & 109 & 1195 & 2.064 & $3.347 \times 10^{-3}$ & $3.347 \times 10^{-3}$ & $0.63598 \times 10^{-3}$ & 1.84 & 0.02 \\
\hline 14 & 110 & 1186 & 2.0455 & $3.373 \times 10^{-3}$ & $3.373 \times 10^{-3}$ & $0.6408 \times 10^{-3}$ & 1.87 & 0.022 \\
\hline 16 & 110 & 1190 & 2.0455 & $3.361 \times 10^{-3}$ & $3.361 \times 10^{-3}$ & $0.6386 \times 10^{-3}$ & 1.87 & 0.022 \\
\hline
\end{tabular}

The values of $\gamma_{\text {int }}$ are the average values of 5 readings.

$r=$ radious of the tip of the pipette $=0.026 \mathrm{~cm}$

Hadkar factor $\mathrm{H}_{1}=-\frac{\left(n^{\text {butanol }} \text { in air) }\right.}{- \text { (n }^{\text {Twee-20 }} \text { in air) }}$

$\mathrm{n}^{\text {butanol }}$ in air $=$ number of drops of butanol in air per $4 \mathrm{ml}=225$

$\mathrm{n}^{\text {Tween-20 }}$ in air = number of drops of aqueous Tween-20 solution.per $4 \mathrm{ml}$

$\mathrm{n}^{\text {Tween-20 }}$ in butanol $=$ number of drops of aqueous Tween-20 solution in butanol

үint $=$ Interfacial tension between aqueous Tween- 20 solution and butanol $=(\mathrm{m} / \mathrm{H} 1) \cdot(\mathrm{g} / 2 \pi \mathrm{r})$

$\mathrm{C}=$ Concentration of aqueous Tween-20 solution .

$\mathrm{g}=$ acceleration due to gravity $=980 \mathrm{~cm} / \mathrm{sec}^{2}$

$v=$ vol. in c.c. of 1 drop of Tween- 20 solution in butanol $=4 / n^{\text {Tween-20 }}$ in butanol

$m=m o\left(\rho-\rho^{\prime}\right) / \rho=$ apparent mass of Tween-20 solution drop in butanol.

$\mathrm{m}_{\mathrm{o}}=$ True mass of Tween-20 solution drop in $\mathrm{gm}=\mathrm{v} . \rho$

$\rho=$ density of the heavier liquid Tween- 20 solution $=1 \mathrm{gm} / \mathrm{cc}$.

$\rho^{\prime}=$ density of the lighter liquid butanol $=0.81 \mathrm{gm} / \mathrm{cc}$

Note : The density of aqueous Tween-20 solution is considered the same as the density of water $=1 \mathrm{gm} / \mathrm{cc}$.

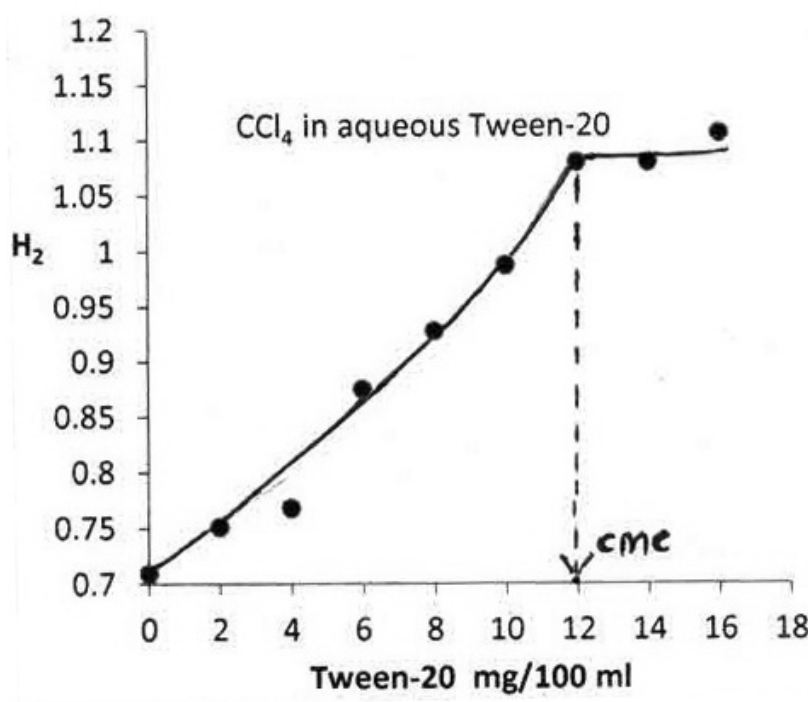

Figure 1: Plot of Hadkar Factor $\mathrm{H}_{2}$ vs concentration of aqueous Tween-20 solutions

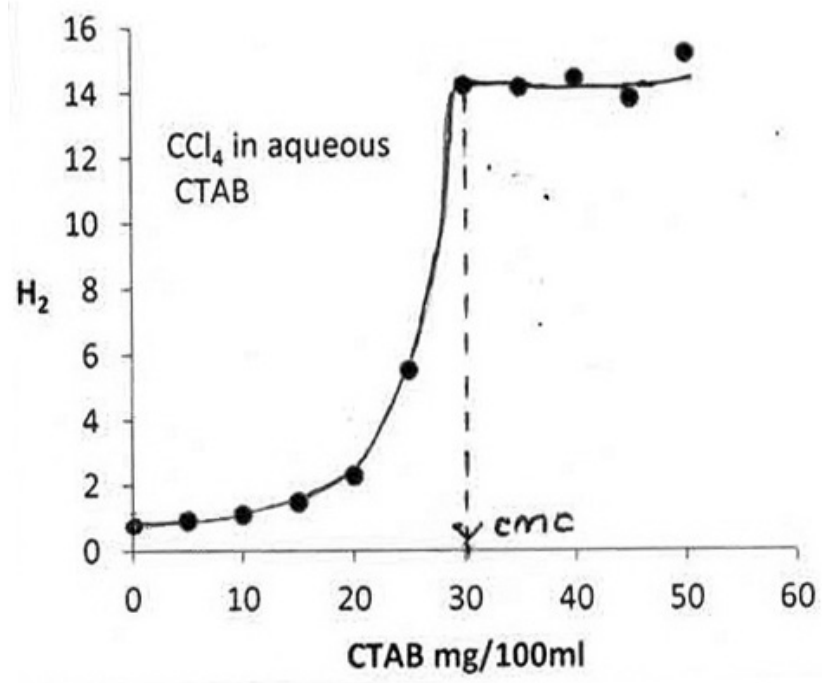

Figure 2: Plot of Hadkar Factor $\mathrm{H}_{2}$ vs concentration of aqueous CTAB solutions 


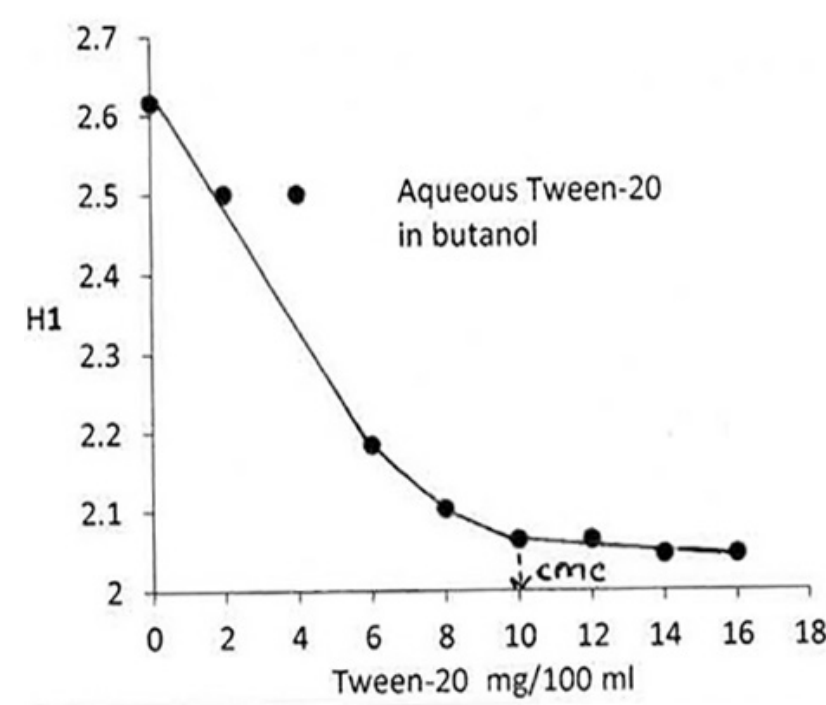

Figure 3: Plot of Hadkar Factor $\mathrm{H}_{1}$ vs concentration of aqueous Tween-20 solutions

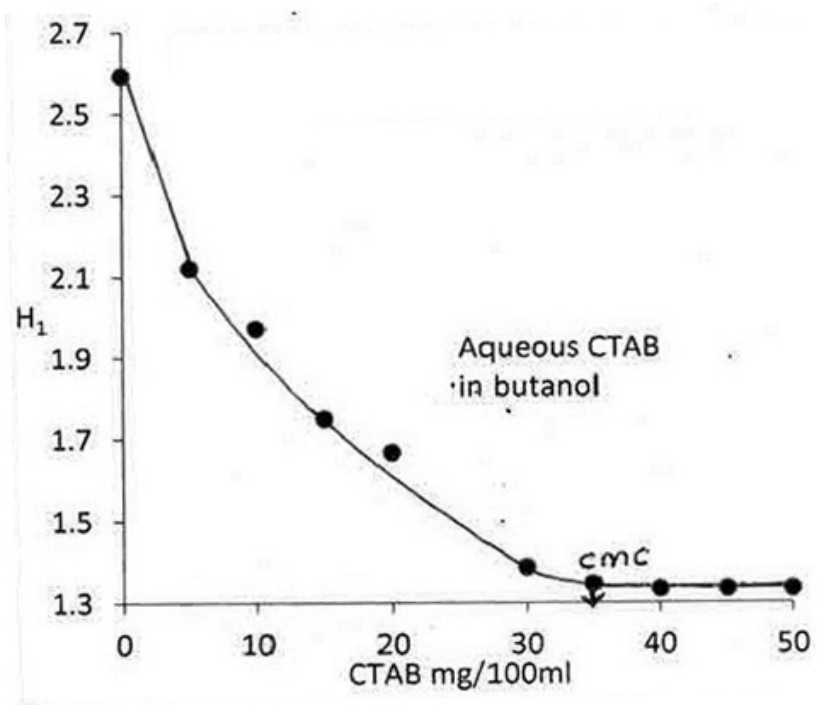

Figure 4: Plot of Hadkar Factor $\mathrm{H}_{1}$ vs concentration of aqueous CTAB solutions

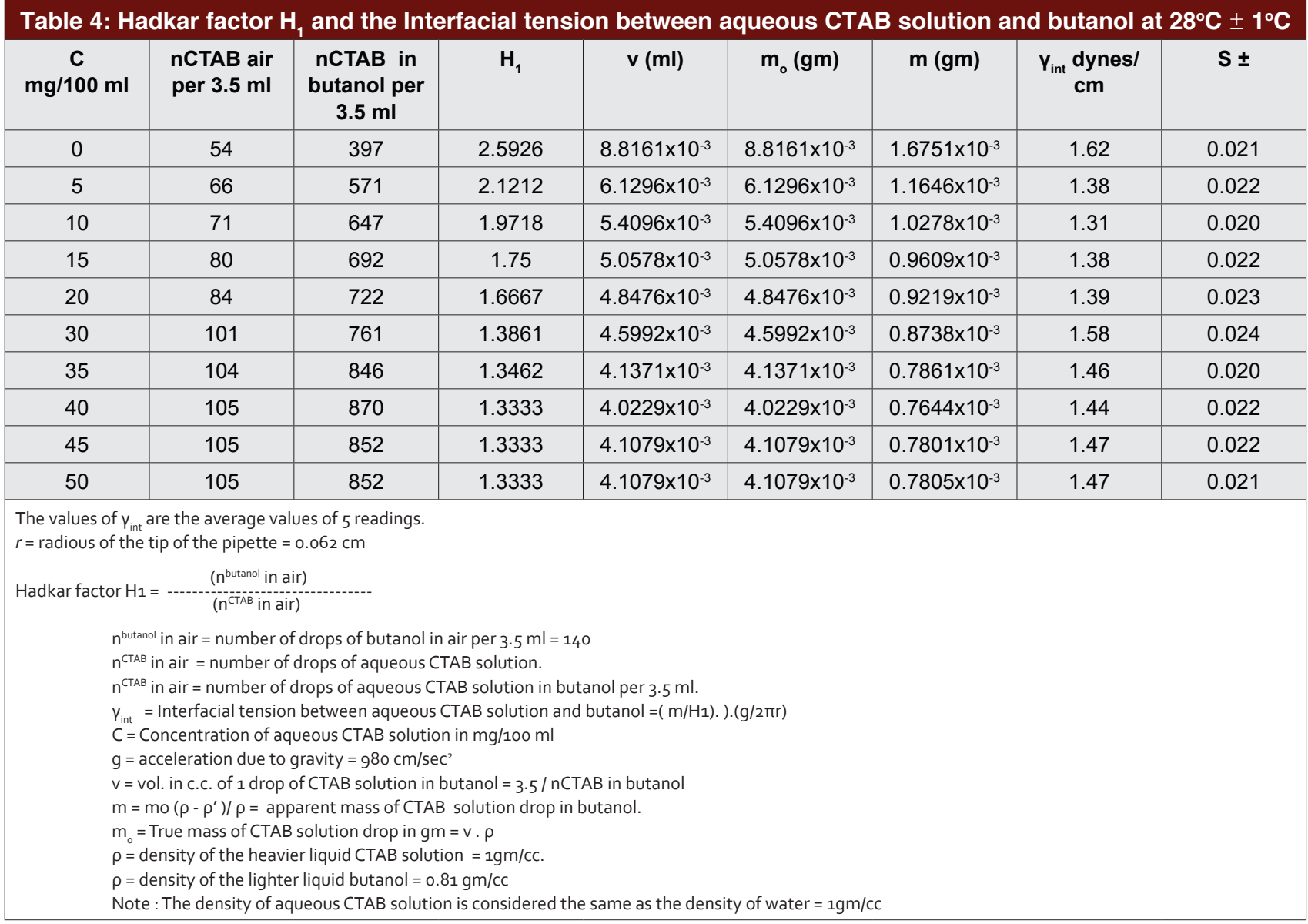

The interfacial tension $\left(\gamma_{\text {int }}\right)$ between organic liquid and the aqueous surfactant solution was calculated using equations (3) and (4) and are reported in the tables 1 to 4. It was found that the Hadkar factor as well as the interfacial tension remains practically constant after the cmc of the surfactant. The plots of Hadkar factor $\mathrm{H}_{1}$ or $\mathrm{H}_{2}$ vs the concentration of the surfactant solution are given in the Figure. 1 to 4 and were used to determine the $\mathrm{cmc}$ of the surfactant. The cmc values of the surfactants Tween20 and $\mathrm{CTAB}$ determined were in close agreement with the reported values and are given in the Table 5.The general equation for the determination of surface tension $\gamma$, of the liquid by drop weight method is $m g=2 \pi r \gamma \cos \theta$-------- (5) 


\section{Table 5: Comparison between the cmc values of the} surfactant.

\begin{tabular}{|c|c|c|}
\hline \multirow[t]{2}{*}{ Surfactant } & \multicolumn{2}{|c|}{ cmc mg/100 ml } \\
\hline & $\begin{array}{l}\text { Determined } \\
\text { Average value }\end{array}$ & Reported \\
\hline Tween-20 & 11 & 9.865 (Note 1) \\
\hline CTAB & 32.5 & 33.48 (Note 2) \\
\hline \multicolumn{3}{|c|}{$\begin{array}{l}\text { Note 1: The } \mathrm{cmc} \text { for Tween-20 obtained from Wikipedia.com } \\
\text { The molecular formula of Tween-20 is } \mathrm{C}_{58} \mathrm{H}_{114} \mathrm{O}_{26} \text { (mol.wt.1227) } \\
\qquad \begin{aligned} \mathrm{cmc}=8.04 \times 10^{-5} \mathrm{moles} / \text { litre }=8.04 \times 10^{-5} \times 1227 \mathrm{gm} / \text { litre } \\
\quad=9.865 \mathrm{mg} / 100 \mathrm{ml} \text {. }\end{aligned} \\
\begin{aligned} \text { Note2 : The } \mathrm{cmc} \text { of } \mathrm{CTAB} \text { (mol.wt. } 364 \text { ) is reported by Sigma Aldrich and is } \\
\text { obtained from, www.sigmaaldrich.com } \\
\text { The } \mathrm{cmc} \text { of CTAB }=0.92 \text { milli moles / litre } \\
=0.92 \times 10^{-3} \times 364 \mathrm{gm} / \text { litre } \\
=33.48 \mathrm{mg} / 100 \mathrm{ml}\end{aligned}\end{array}$} \\
\hline
\end{tabular}

where, $\mathrm{m}$ is the mass of the liquid drop about to detach from the tip of the pipette of inner radius $r$ and $\theta$ is the angle of contact between the liquid and the glass. The equations (3) and (4) used to determine the interfacial tension, replace $\cos \theta$ by Hadkar Factor $\mathrm{H}_{1}$ and $\mathrm{H}_{2}$ in the equations (5). The comparison of the equations (3), (4) with equation (5) indicates that Hadkar Factor $\mathrm{H}_{1}$ and $\mathrm{H}_{2}$ depend on the angle of contact between heavier and lighter liquids and the glass and also probably on the angle of contact between the two liquids. This however has to be proved. The exact physical significance of the Hadkar Factors $\mathrm{H}_{1}$ and $\mathrm{H}_{2}$ is not yet clear.

\section{CONCLUSION}

The plot of $\gamma_{\text {int }}$ vs concentration of surfactant solutions is normally used to obtain cmc of the surfactant because the value of $\gamma_{\text {int }}$ remains practically constant after the cmc. Since Hadkar factor $\mathrm{H}_{1}$ (or $\mathrm{H}_{2}$ ) is also found to remain constant after the cmc of the surfactant, the plot of $\mathrm{H}_{1}$ or $\mathrm{H}_{2}$ vs the surfactant solution concentration was used to obtain the $\mathrm{cmc}$ of the surfactant. The $\mathrm{cmc}$ values obtained from these plots are in good agreement with the reported values (Table 5).

\section{ACKNOWLEDGEMENT}

We thank the Trustees of Mumbai Educational Trust Mr. Chhagan Bhujbal, Sameer Bhujbal, Pankaj Bhujbal for the laboratory facilities provided to conduct the experimental work.

\section{REFERENCES}

1. Handbook of Detergents Part A, edi. Guy Brose, Marcel Dekker, Inc, Vol.82, p.7

2. Martin AN. Martin's Physical Pharmacy, Pharmaceutical Sciences, Sinko P.J., Lippincott Williams \& Wilkins, $5^{\text {th }}$ edition; p.473.

3. Ramington, The Science and Practice of Pharmacy, Edi. Loyd V. Allen, Philadelphia College of Pharmacy, $22^{\text {nd }}$ edition; 2013, p.728.

4. Paddy JF. Surface and Colloid Science, Vol. I, Edi. Matijevic E., Johm Wiley and Sons, New York; 1969. p.101.

5. Bentley's Text Book of Pharmaceutics, Ed. Rawlins, $8^{\text {th }}$ Edition; 2010, p.51.

6. Ramington, The Science and Practice of Pharmacy, Edi. Loyd V. Allen, Philadelphia College of Pharmacy, $22^{\text {nd }}$ edition; 2013. p.725.

7. Hadkar UB, Ravindra RP. Interfacial Tension using a simple laboratory technique. IJPER. 2009; 43(2): 187-91.

8. Glasstone S. Text book of Physical Chemistry, London, Mcmilan \& Co. Ltd.; 1962. p. 366. 